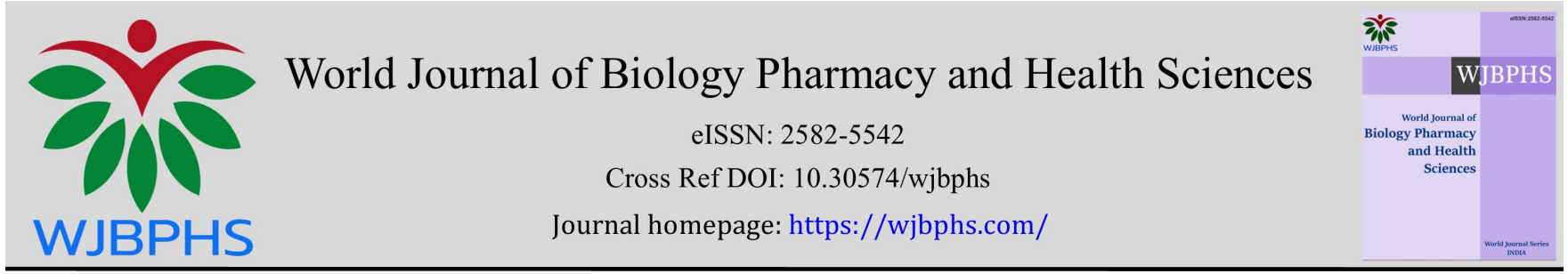

(REVIEW ARTICLE)

\title{
Indigenous chicken "Kolonto" and food security in Gaya
}

\author{
Moussa Hassan Ousseini ${ }^{1,}{ }^{*}$, Issa Salissou ${ }^{2}$, Hima Maman Karmadini ${ }^{1}$ and Bakasso Yacoubou ${ }^{1}$ \\ ${ }^{1}$ Biology Department, Faculty of Sciences and Technics, Abdou Moumouni University of Niamey, Niamey, Niger. \\ ${ }^{2}$ Animal Production Department, National Institute for Agronomic Research of Niger, Niamey, Niger.
}

World Journal of Biology Pharmacy and Health Sciences, 2021, 06(02), 014-022

Publication history: Received on 01 April 2021; revised on 05 May 2021; accepted on 08 May 2021

Article DOI: https://doi.org/10.30574/wjbphs.2021.6.2.0044

\begin{abstract}
This study was initiated to characterize the economic profitability of the breeding of the local chicken "Kolonto" in the Gaya department. A survey was conducted in 15 localities in the 6 communes of the Gaya department. The results showed that 29\% of "Kolonto" local chicken keepers are women. The price of local chicken "Kolonto" varies between 4 to 8 USD according to $50 \%$ of producers. This economic gain, linked to the sale of local chicken, allows producers to make family expenses and meet their health care needs. Thus, the breeding of local chicken "Kolonto" contributes greatly to household food security and community resilience. However, the breeding of "Kolonto" chicken ecotype is between many constraints whose main one is diseases (59.3\%). It is clear that the development of the sector necessarily involves strengthening surveillance of avian diseases, combined with veterinary monitoring and supervision of producers.
\end{abstract}

Keywords: Food security; Kolonto; local chicken; Family poultry; Gaya

\section{Introduction}

Family poultry is at the forefront of poultry production in many developing countries. It would bring together more than $77 \%$ of the domestic poultry population with a wide variation across countries: $30 \%$ in Zimbabwe, 53\% in Côte d'Ivoire, $70 \%$ in Kenya, $80 \%$ in Nigeria, $86 \%$ in Tanzania [1]. The value of family poultry to producers is that it requires low levels of inputs, contributes significantly to food security, poverty alleviation, and sound ecological management of natural resources and source of employment for disadvantaged groups [2,3].

In Niger, poultry breeding is dominated by family poultry, which accounts for $96 \%$ of all local breeds combined, compared with 3\% for modern breeds. In the total of indigenous poultry, chicken accounts for 55\% [4]. In the department of Gaya in Niger, there is a large local chicken ecotype called "Kolonto" which is considered as a traditional broiler [5].

In the context of climate change, local communities face a number of risks that lead them into a vicious cycle that progressively diminishes their resilience and thus promotes their vulnerabilities. Thus, the development of family poultry is an opportunity for local communities. In fact, it is known in Niger that producers who have lost everything after a drought or other natural disaster resort to poultry farming, which will allow them later to acquire small and ruminants.

This study is carried out to discover the economic advantages related to the breeding of the local chicken "Kolonto" in order to understand its contribution in the reinforcement of the resilience of the local communities of the department of Gaya.

\footnotetext{
* Corresponding author: Moussa Hassan Ousseini

Biology Department, Faculty of Sciences and Technics, Abdou Moumouni University of Niamey, Niamey, Niger.
} 


\section{Material and methods}

\subsection{Characteristics of the Study Area}

The department of Gaya, part of our study, is located in the southwestern tip of Niger Republic between $3^{\circ} 6$ "and $3^{\circ} 51^{\prime \prime}$ East longitude and between $11^{\circ} 42$ "and $12^{\circ} 56^{\prime \prime}$ North latitude (Figure 1). It covers an area of approximately $2556 \mathrm{~km} 2$ [6] and is limited to the North-East by the Dioundiou Department,

To the North-West by the Dosso Department, to the East and South-East by the Federal Republic of Nigeria, to the SouthWest by the Republic of Benin. The department of Gaya is composed of six communes: Bana, Bengou, Tanda, Tounouga, Yelou and urban commune of Gaya (figure 1).

The climate of the Gaya area is the kind of North-Sudanese type with a rainfall between 600 and $1000 \mathrm{~mm}$. The floristic composition is dominated by a large dense combretaceae population in the plateau zone [7].

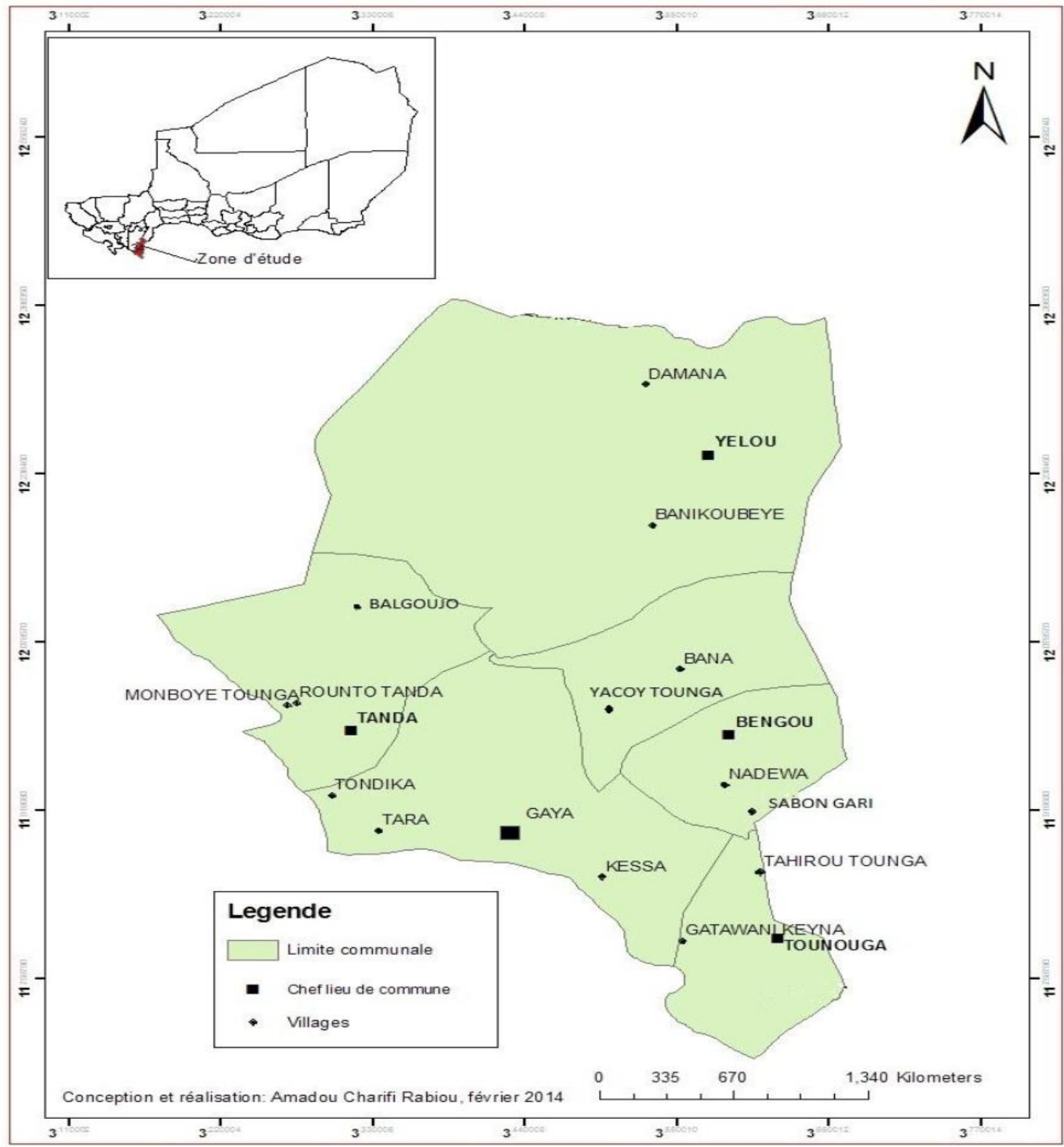

Figure 1 Location of the study area 


\subsection{Data collection process}

A survey was carried out in 15 villages distributed in the 6 communes that count the department of Gaya. The villages are chosen by local farmers in each village. The study lasted 2 months (from August to September 2013). The target group of this survey is the producers of the local chicken. A total of 90 producers were involved in this survey. The ratio was 15 producers per village. Questionnaire was administered to producers in order to collect information on the production of "Kolonto" local chicken ecotype. The interviews were semi-structured and the questionnaire were administered with the help of a translator from French to the local language spoken in the area (Zarma, Dendi). Most often, the interviews are done in the morning during our field trips by taking care to inform the breeders through the village chief. However, we have done some interviews in the evening because of the occupations of the breeders because of their farms work.

\subsection{Data analysis}

All the data collected were processed with Excel 2007 and subjected to a descriptive analysis with SPSS software (Statistical Package for Social Sciences.) Version 18.0.

\section{Results}

\subsection{Profile of the producers of the local chicken "Kolonto"}

The analysis of Figure 2 shows that the majority of "Kolonto" producers are men (71\%).

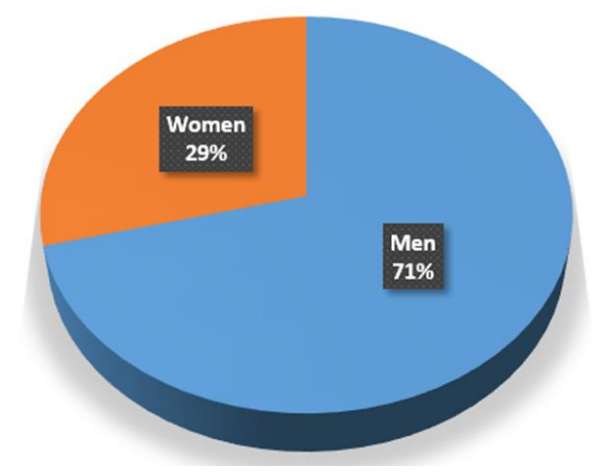

Figure 2 Gender of the producers of the local chicken "Kolonto" in the department of Gaya

Agriculture and breeding are the main activities practiced by the producers of the local chicken "Kolonto" in the department of Gaya. In addition to these activities, $40 \%$ of producers have other secondary occupations (fishing, trading).

\subsection{Modes of breeding behavior of the local chicken "Kolonto"}

There is no suitable habitat for the "Kolonto" local chicken (Figure 3: a and b). Scavenging is the production system of "Kolonto" local chicken. However, the support of the Community Action Program II (PAC II) and of the National Institute for Agronomic Research of Niger (INRAN) has allowed some producers to have small poultry house. Producers who have benefited from this help keep their chicken in free range system the day and close them at night (Figure 3: c and d). 

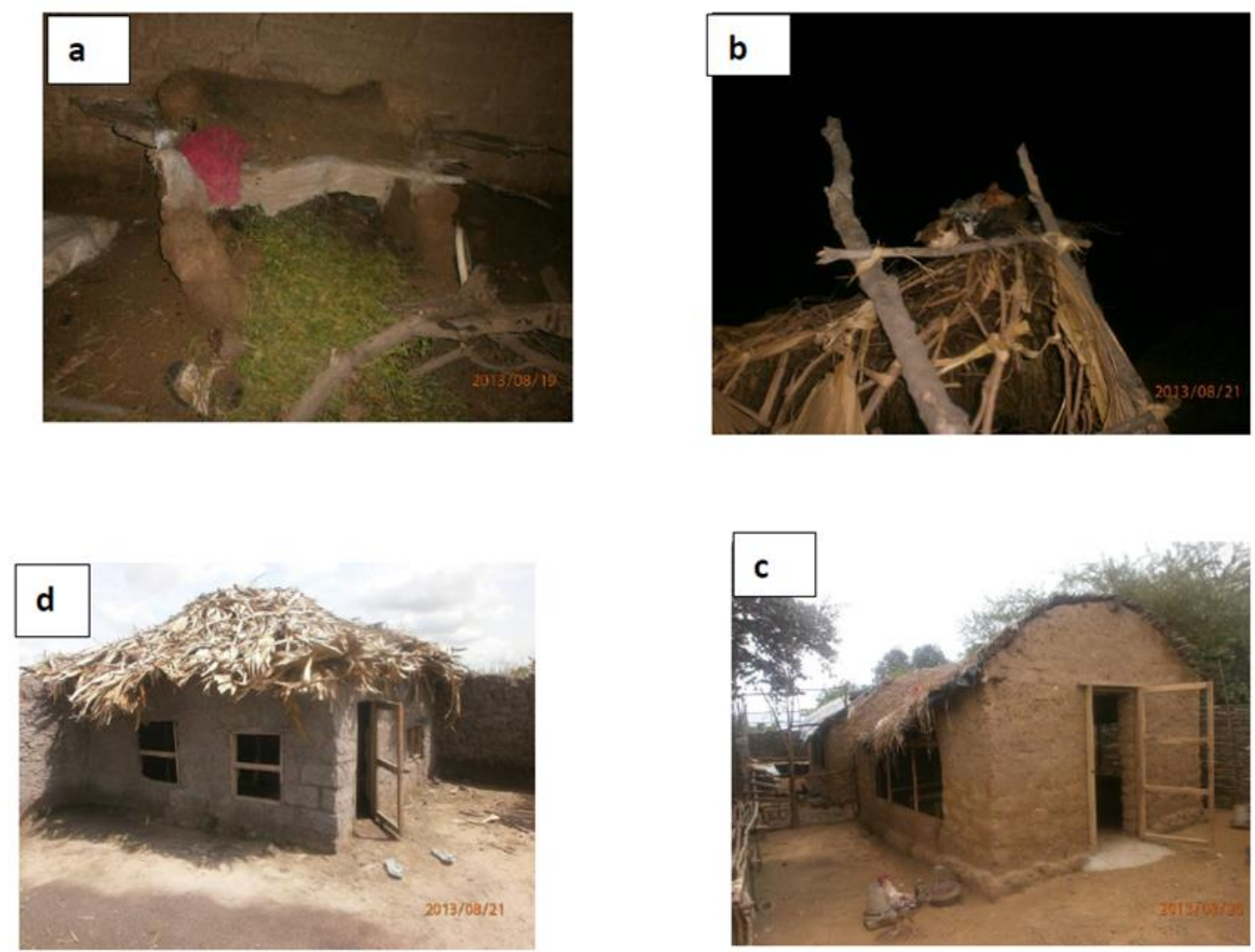

Figure 3 Home of the local chicken "Kolonto" in the department of Gaya: a and b: Habitat of the chickens, c: house made with the support of INRAN in Kessa village, d: house made by Community Action Program II (PACII) support.

\subsection{Economic aspect of the breeding of the local chicken "Kolonto" ecotype}

Mode of acquisition: Figure 4 shows the different modes of acquisition of the local chicken "Kolonto" at startup. We find that $47 \%$ of the producers bought their first chicken at breeding startup.

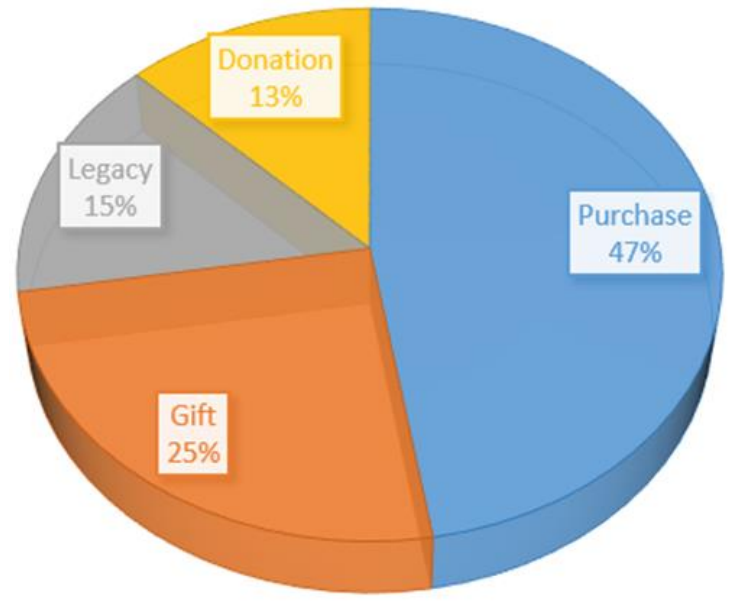

Figure 4 Modes of acquisition of chickens in the department of Gaya

\subsection{Number of eggs per brood and incubation duration of the local chicken "Kolonto"}

Of all the responses, the number of eggs per brood varies between 3 and 22 eggs. But for many producers the number of eggs varies from 8 to 10 eggs (45\%), (Figure 5). 


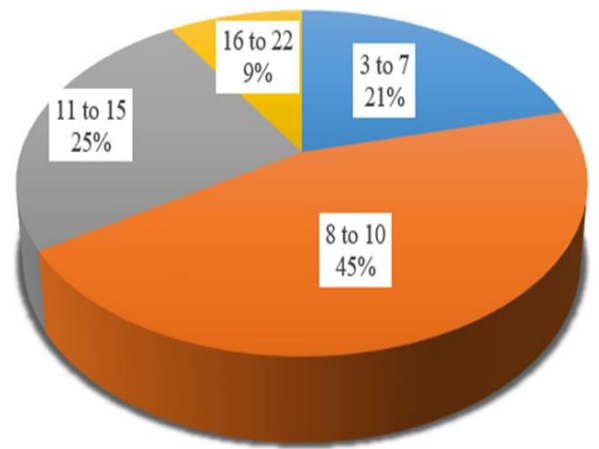

Figure 5 Number of eggs per brood of the local chicken "Kolonto" in the department of Gaya

Figure 6 shows the brooding time of the local chicken "Kolonto" in the department of Gaya. This duration is between 15 to 18 days for many producers $(47 \%)$.

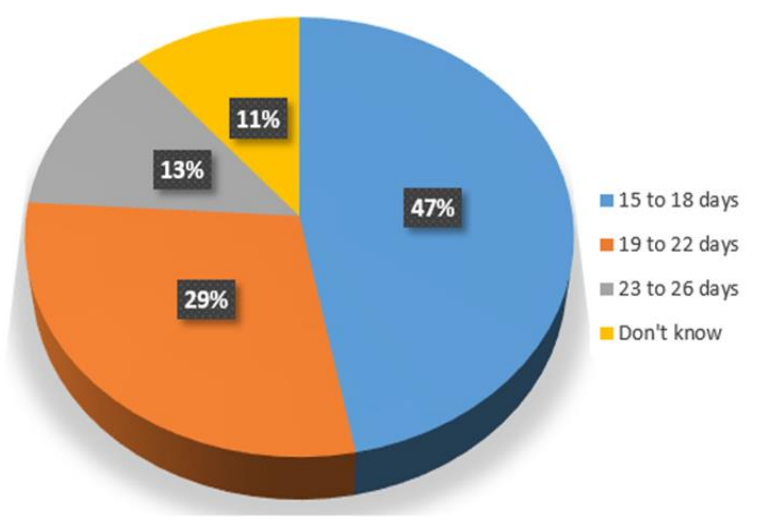

Figure 6 The brooding time of the local chicken "Kolonto" in the department of Gaya.

\subsubsection{The beginning age of the slaughter of the local chicken "Kolonto"}

According to producers, compared to other local chicken ecotype, the "Kolonto" ecotype is growing rapidly. Based on the majority of producers (52.6\%), the local chicken "Kolonto" can be slaughtered at the age of 2 to 4 months (Figure 7).

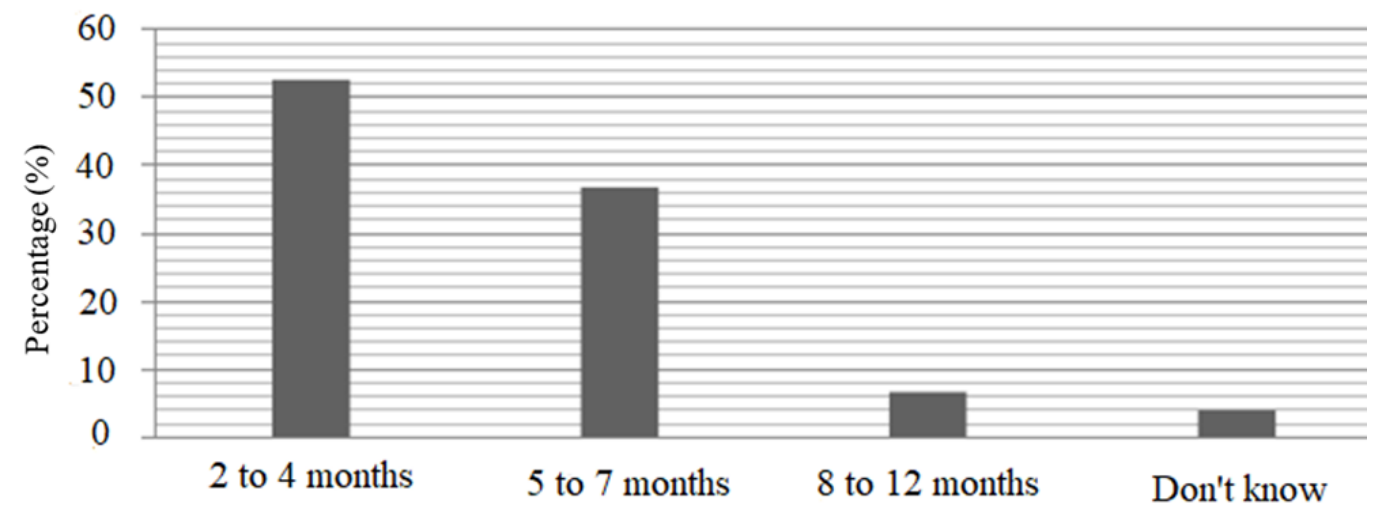

Figure 7 The age of slaughter of "Kolonto" local chickens in the Gaya department

\subsubsection{Cost of the local chicken "Kolonto"}

The price of the "Kolonto" chicken varies according to its size, which is also a function of its age and weight. For many producers (50\%), this price varies between 4 to 8 USD (Figure 8 ). 


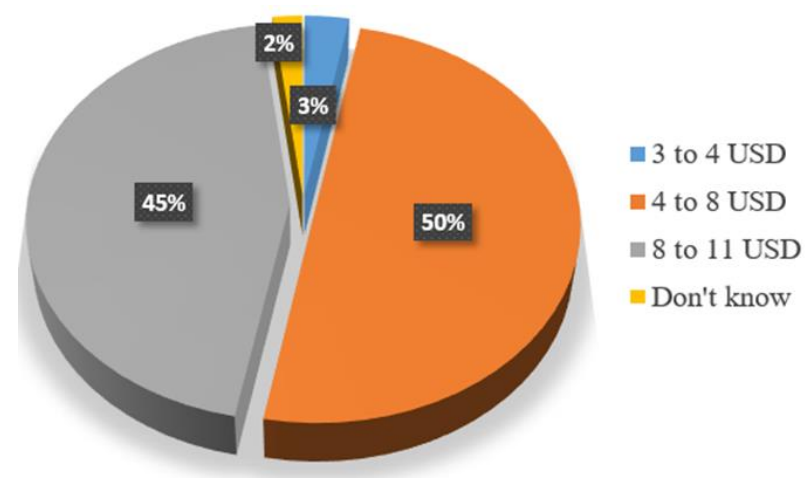

Figure 8 Producer prices of the local chicken "Kolonto" in the department of Gaya.

\subsubsection{Profit from raising the local chicken "Kolonto"}

The keeping of the local chicken "Kolonto" ecotype is very important to the rural population because of the cost of these ecotype at the market. Sales of the local chicken "Kolonto" allow producers to:

- $\quad$ Make family expenses (purchases of clothes, condiments, cereals ...),

- Make the expenses for the feast (Tabaski, Ramadan ...),

- Buy some livestock breed (cattle, sheep, goats...),

- Satisfy the needs of health care,

- Pay fertilizers for field crops,

The local chicken "Kolonto" is also used as a source of protein for the consumption of families and also allows breeders to make a contribution in several ceremonies (baptism, marriage ...).

\subsection{Constraints related to the breeding of the local chicken "Kolonto"}

Several problems hinder the breeding of the local chicken "Kolonto". According to 59\% of producers, the most common problem is susceptibility to disease (Figure 9).

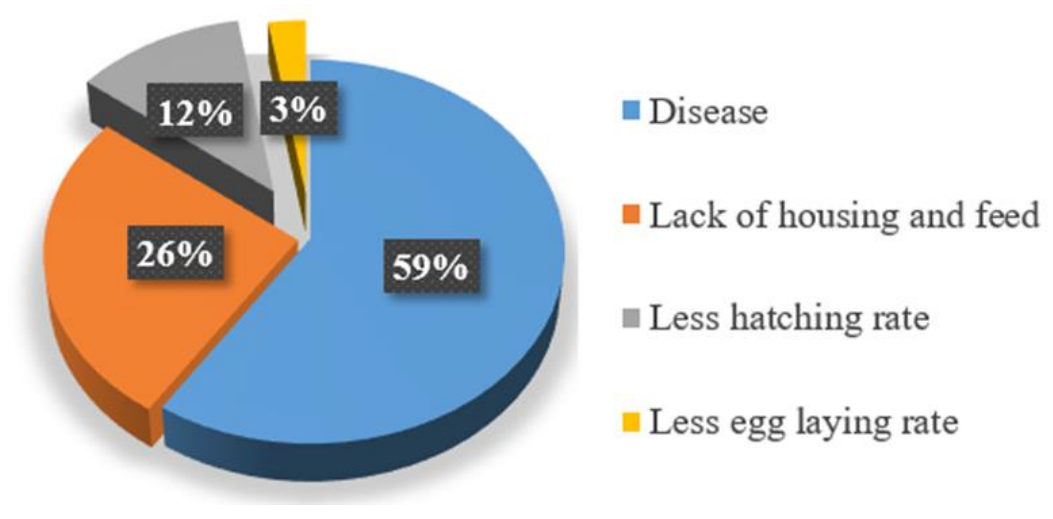

Figure 9 Constraints related to the breeding of the local chicken "Kolonto" in the department of Gaya.

\section{Discussion}

According to this study, the keeping of the local chicken "Kolonto" is more practiced by men (71.1\%) than by women in the department of Gaya. This is not the case in Cameroon [8] and Gambia [9] where this type of breeding is practiced by more women. The same results were found by Amadou et al., [10] in Dakoro (Niger) where the proportion of men is $78 \%$. These results may be biased by the fact that men prefer to answer questions instead of their wives, probably to avoid direct contact with visitors. Agriculture and livestock are the main activity of these producers. Some producers $(40 \%)$ have other secondary activities. These activities allow them to occupy their time in the 12 months of the year.s 
The "Kolonto" ecotype is a type of large local chicken that has a high sale price and defies the selling price of other local chicken ecotypes. The rapid growth of "Kolonto" allows producers to earn more in their breeding. Some breeders bought themselves small ruminants and satisfied a lot of their financial needs. The local chicken "Kolonto" is like a "current account" of the breeder that allows him to meet many of his small needs without recourse to others. Thus raising the local chicken "Kolonto" is a solution to help the underprivileged to get out of poverty and malnutrition. Breeding the local chicken "Kolonto" is a good instrument of integration in society because it allows the breeder to play his role in society.

The local chicken "Kolonto" does not have a suitable habitat. The few rare habitats are constructed of locally available materials. Some breeders leave their chicken laying in their room or in kitchens. Others chickens perch on tree branches and / or rest on roofs of hangars. This exposes them to certain threats such as predation and thus increases the mortality rate. This mortality significantly reduces the size of the local chicken population "Kolonto" and therefore reduces the farmer's income. This result was found by Fotsa [8] and Abubacar et al., [10] who worked on the local chicken respectively in Cameroon and Nigeria.

Scavenging is the main local chicken production system of the local chicken "Kolonto" in the Gaya department. It is a traditional method that exposes chickens to certain diseases such as Newcastle disease that causes several damage to farmers. This result was also reported by Fotsa [8] and Gawande et al., [12] who worked on the local chicken respectively in Cameroon and India.

The local chicken "Kolonto" does not lay many eggs and has a low hatching rate. This type of local chicken is also susceptible to diseases. These problems should not discourage the valorization of the breeding of the local chicken "Kolonto" because there are solutions. These solutions are based on the constant monitoring of chickens through an improvement of their habitat, a rich and complete diet and a contribution in veterinary products. This will result in increased producer income.

\section{Conclusion}

Local chicken "Kolonto" plays an important socio-economic role in the Gaya region. This is mainly due to its high market price, which allows it to contribute to the fight against poverty and the food security of producers. In order to fight poverty in rural areas, the challenge is to increase production, while meeting the cultural expectations of farmers. For this, technical constraints can be minimized by emphasizing the supervision of herders, giving them the means to access better sanitary control and the best food combinations that can avoid the scavenging of the "Kolonto". These improvements in rearing conditions could increase the productivity of this local chicken ecotype. This would be a cheap source of quality protein as well as a way to diversify producers' income.

\section{Compliance with ethical standards}

\section{Acknowledgments}

The authors would like to thank, The National Institute of Agronomic Research of Niger for having funded the data collection from this work, the departmental livestock service of Gaya for valuable assistance in the selection of villages during the data collection.

\section{Disclosure of conflict of interest}

All authors declare no conflict of interest in this study.

\section{Statement of informed consent}

All the producers who participated in this survey were first informed about the main purpose of the study and their participation was voluntary and anonymous. A verbal agreement was obtained from each producer at the beginning of his interview.

\section{References}

[1] Sonaiya EB. African Network on Rural Poultry Development. Progress Report. November 1989 to June 1995. Proceedings ANRPD Workshop, Addis Ababa. Ethiopia. 1997; 134-143. 
[2] Guèye EF. Village egg and fowl meat production in Africa. World's Poult. Sci. J. 1998; 54: 73-86.

[3] Guèye EF. Gender issues in family poultry production systems in low-income food-deficit countries. American Journal of Alternative Agriculture. 2003; 18(4): 185-195.

[4] RGAC. Analyse des résultats des enquêtes sur les marchés à bétail et le cheptel aviaire. Recensement général de l'agriculture et du cheptel 2005-2007. Projet GCP/NER/041/EC, MDA/MRA. 2008; 99.

[5] Moussa Hassan Ousseini, Issa Salissou, Hima Karmadine, Bakasso Yacoubou. Morpho-Biometric Characterization of the "Kolonto" Local Chicken Ecotype in Gaya Area. International Journal of Natural Resource Ecology and Management. 2019; 4(4): 83-88.

[6] Rabiou AC. Les conflits autour des forêts classées de Fogha Béri et Koulou dans la région de Dosso. Mémoire de master géographie. Faculté des Lettres et Sciences Humaines. 2014; 68.

[7] Dambo L. Usages de l'eau à Gaya (Niger): entre fortes potentialités et contraintes majeures. Thèse de doctorat. $2007 ; 355$.

[8] FotsaJ C. Caractérisation des populations de poules locales (gallusgallus) au Cameroun. Mémoire de thèse. 2008; 301.

[9] Bonfoh B, Ankers P, Pfister K, Pangui LJ, Toguebaye BS. Répertoire de quelques Contraintes de l"Aviculture villageoise en Gambie et Propositions de Solutions pour son Amélioration. 2007; 13.

[10] Amadou Moussa B, Idi A, Benabdeljelil K. Aviculture familiale rurale au Niger: alimentation et performances zootechniques.RIDAF. 2010; 19(1): 5-12.

[11] Abubacar MB, Ambali AG, Tamjdo T. Elevage de poulets villageois : contraintes limitant la production de poulets villageois dans certaines zones du Nigeria et du Cameroun. RIDAF. 2007; 17(1\&2): 59-64.

[12] Gawande SS, Kalita N, Barua N, Saharia KK. Elevage du poulet local en milieu rural d"Assam (Inde). RIDAF. 2007; 17(1\&2):15-29.

\section{Author's short biography}

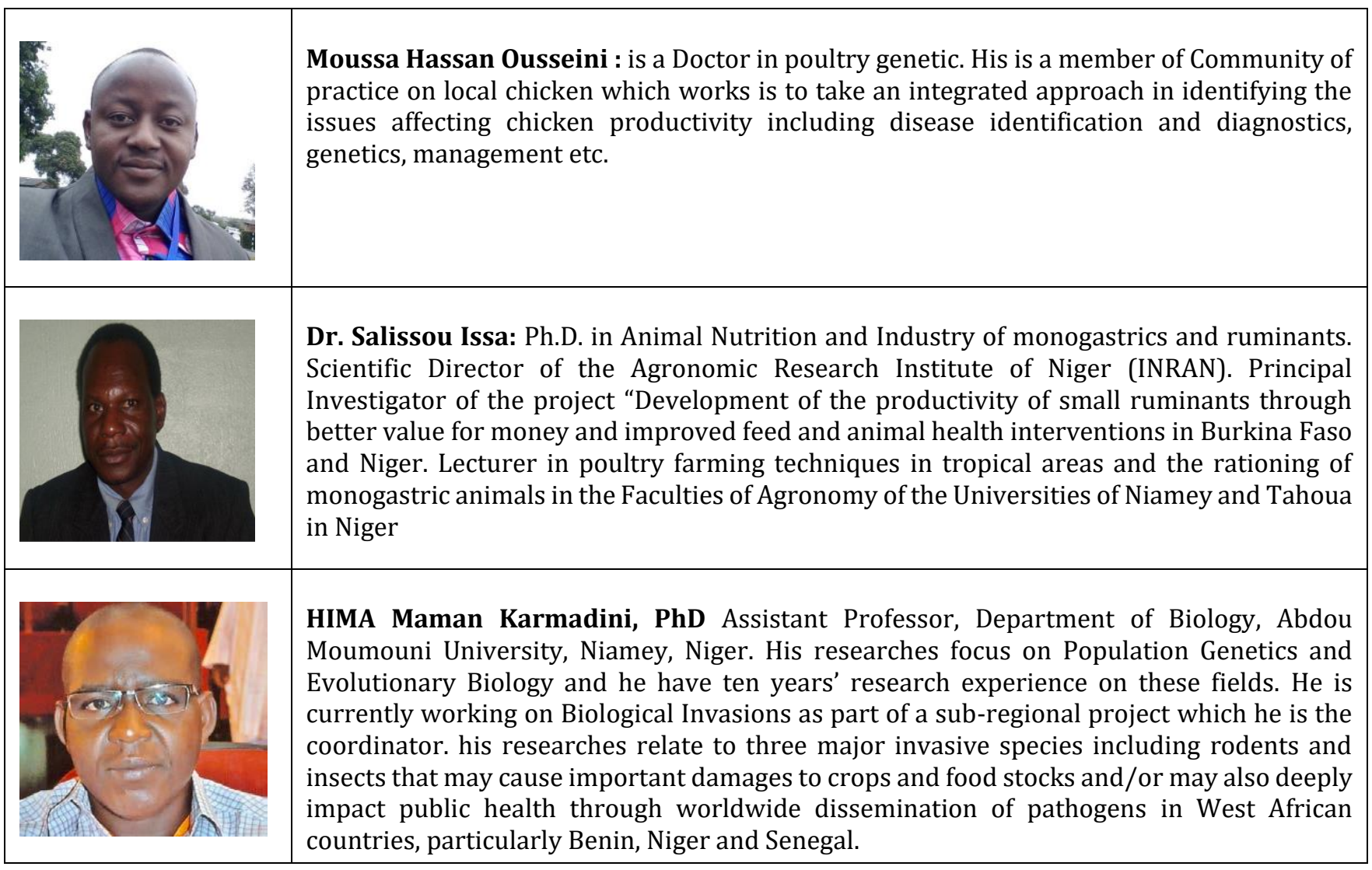




\begin{tabular}{|l|l|} 
Pr. Yacoubou Bakasso: is the Dean of Faculty of Sciences and Technics. He is specialist in \\
genetics and plant breeding. Person in charge of Laboratory of management and \\
valorization of Biodiversity in Sahel, Biology department of Faculty of Sciences and Technics \\
of Abdou Moumouni University of Niamey, Niger.
\end{tabular}

